Chicago-Kent College of Law

Scholarly Commons @ IIT Chicago-Kent College of Law

All Faculty Scholarship

Faculty Scholarship

February 2005

\title{
Engendering Legal History
}

Felice J. Batlan

IIT Chicago-Kent College of Law, fbatlan@kentlaw.iit.edu

Follow this and additional works at: https://scholarship.kentlaw.iit.edu/fac_schol

Part of the Legal History Commons

\section{Recommended Citation}

Felice J. Batlan, Engendering Legal History, 30 Law \& Soc. Inquiry 823 (2005).

Available at: https://scholarship.kentlaw.iit.edu/fac_schol/68

This Article is brought to you for free and open access by the Faculty Scholarship at Scholarly Commons @ IIT Chicago-Kent College of Law. It has been accepted for inclusion in All Faculty Scholarship by an authorized administrator of Scholarly Commons @ IIT Chicago-Kent College of Law. For more information, please contact jwenger@kentlaw.iit.edu, ebarney@kentlaw.iit.edu. 


\section{Engendering Legal History}

Felice Batlan

Ariela Dubler. In the Shadow of Marriage: Single Women and the Legal Construction of the Family and the State. Yale Law Journal 112 (2003): 1641-715.

Katherine M. Franke. Becoming a Citizen: Reconstruction Era Regulation of African American Marriages. Yale Joumal of Law and the Humanities 11 (1999):251-310.

Kenneth Mack. A Social History of Everyday Practice: Sadie T. M. Alexander and the Incorporation of Black Women into the American Legal Profession. Cornell Law Review 87 (2002):1405-474.

Amy Dru Stanley. From Bondage to Contract: Wage Labor, Marriage, and the Market in the Age of Slave Emancipation. Cambridge, U.K.: Cambridge University Press, 1998. Pp. 294. $\$ 65.00$ cloth; $\$ 22.99$ paper.

Barbara Young Welke. Recasting American Liberty: Gender, Law, and the Railroad Revolution, 1865-1920. Cambridge, U.K.: Cambridge University Press, 2001. Pp. 426 . $\$ 80.00$ cloth; $\$ 25$ paper.

In the past decade a host of scholars have begun to explore the interconnections between gender and legal history. This literature is in intense dialogue with mainstream legal history as well as with gender and women's history. Thus, by its very nature, it is deeply interdisciplinary. Moreover, such scholarship prompts us to rethink the dominant narratives of legal history and the role of law in producing and reflecting cultural and social norms. Engendering legal history means more than just writing women into the dominant history of law. Rather, it produces a new history, creating possibilities of re-narrations and the potential for fresh interpretations.

The study of gender and legal history is part of the larger genre of critical legal history. Robert Gordon broadly describes such history as "any approach

Felice Batlan is associate professor of law, Tulane Law School; adjunct professor of history, Tulane University. For their comments and insights, I thank Richard B. Bernstein, Lloyd Bonfield, Marjorie Kornhauser, Pam Metzger, Jancy Hoeffel, Judith Schafer, and Jonathan Nash. 
to the past that produces disturbances to the field - that inverts and scrambles familiar narratives of stasis, recovery or progress" (Gordon 1997, 1024). Surprisingly, however, whereas histories focusing on women and gender have flourished in history departments since the 1970s, similar work in legal history has come late and hesitantly. Yet, using gender as a mode of analysis can expose and controvert some of our basic assumptions about citizenship, law, and the construction of the liberal state.

For example, what happens to liberalism's vaunted protection of property and deference to contract when coverture is read into the law ${ }^{1}$ How does gender account for changes in law that historians have traditionally interpreted as the result of economic change? How does our understanding of the individual's relationship to the state change when domestic relations law stands not at the periphery of law, but at its core? How do we account for women, including African American women, as legal actors both partaking of and subverting sanctioned cultural narratives? How does a gendered analysis redefine and reposition the dichotomous spheres of the public and private, so that their boundaries are blurred, or even erased?

This essay explores these broad questions by examining some recent scholarship on gender and legal history. ${ }^{2}$ In doing so, it extrapolates what these works have in common, how they challenge traditional legal history, and how they use gender as a method of historical analysis. The literature that I examine in this essay constitutes relatively new scholarship, and collectively represents the diversity of work that is being produced in the field. Yet this very diversity - the richness and depth of the literature-prompts the question of what these works have in common, methodologically and substantively. For example, Amy Dru Stanley's book is a wide-ranging work on the social, cultural, and legal understanding of contract during the postbellum period; by contrast, Kenneth Mack's article focuses on one African American woman lawyer's life in the twentieth century. Yet at the core of this diverse literature on gender and legal history is an understanding that analyzing gender changes our received understandings of American legal history.

\section{LOCATING GENDER IN HISTORY}

Twenty years ago, Joan Scott's pathbreaking article, "Gender: A Useful Category of Historical Analysis" (1986), called for a move away from

1. Coverture was a common law doctrine by which, upon marriage, a wife's property became her husband's. She lost the ability to make contracts in her own name, own her own wages, bring a lawsuit, or own property. Claudia Zaher (2002) provides a readily accessible annotated bibliography of the scholarship on coverture.

2. By no means does the scholarship in this essay reflect the entire body of literature on gender and U.S. legal history. For example on the history of family law see Grossberg 1985; Minow 1985; Hasday 2002. On divorce law, see Cahn 2002; Basch 1999. On married women's 
women's history to a more complex concept of gender. Scott argued that gender is not merely a substitute for the biological category "woman," but rather represents a relational understanding of the categories "men" and "women." To speak of women is also to speak of men. Further, Scott explained that gender and the hierarchies that it produces deeply implicate structures of power. Invoking such theories, Scott called for a recognition of gender as "a primary way of signifying relationships of power" $(1986,44)$.

The historian's mission was to understand exactly how during specific historical periods gender functioned as a metaphor for power while also producing the material conditions for the exercise of power. In other words, gender, like race and class, is at least one way through which power becomes systematized, articulated, and legitimized. ${ }^{3}$ Relations of power, however, are in continual flux, seldom complete, historically specific, often unstable, and in constant need of relegitimation through new configurations and discourses of gender. In part, such contestations are produced because gender systems are often internally inconsistent and produce resistance. Analyzing gender is particularly fruitful for legal historians because law, like gender, is a principal means through which power becomes effectuated-that is, made real and material.

As scholars have recognized gender as a social construction about power, the changing meanings and constructions of masculinity have also become a field of inquiry. This development is crucial to a historical analysis of law and creates a new constellation of questions. What, at particular moments in time, does it mean to be masculine and to perform masculinity? How might masculinity relate to the role of lawyers, the construction of law, the supposed laissez-faire state, the roles of a husband and father? How did masculinity shape the way men made legal claims and articulated legal rights? ${ }^{4}$

When reviewing the field of legal history and gender, we immediately notice that so much of the literature examines topics and issues from the nineteenth century. This chronologized focus makes sense. The nineteenth century provides extraordinarily fertile terrain for the legal historian, as that century witnessed the rise of the early women's rights movement, the prolonged transition from slavery to freedom, coverture and subsequent married women's property acts, the adoption of the Fourteenth Amendment, and the always-incomplete, continuing creation and subversion of the separate

property acts and women's labor, see Siegel 1994a, b; Chused 1985. On nineteenth-century feminists use of tax protests, see Jones 1994. On immigration, see Abrams 2005. For synthetic works on the history of U.S. women and the law, see Hoff-Wilson 1991; Van Burkleo 2001.

3. A number of works outside the field of U.S. legal history employ such an understanding of gender and power; see Findlay 1999, examining the politics of race and sex in Puerto Rico; Stoler 1995, examining the regulation and production of sexuality in the colonial context; Walkowitz 1992, exploring gendered discourses of crime and sex in Victorian London.

4. Grossberg 1990 offers a compelling discussion of lawyers and masculinity in the early nineteenth century. See Carnes and Griffen 1990 for essays on history and masculinity. Nye 2005 has recently provided an excellent overview of the literature on masculinity. 
spheres of the male market and the feminine home. Even listing these topics requires us to confront the porous boundaries between state regulation, the public, the family, and the private. ${ }^{5}$

\section{EMANCIPATION, MARRIAGE, AND CITIZENSHIP}

Each of these issues is addressed in Amy Dru Stanley's From Bondage to Contract. The work explores the contradictions, contestations, and ambiguities in mid-to late-nineteenth-century political, economic, and legal thought. Stanley focuses her analysis on how postbellum legal and political discourses attempted to delineate concepts of slavery and freedom, and the central role that contract and the market played in those efforts. Stanley posits that "contract as a world view" formed the principal ideological and epistemological undergirding of nineteenth-century legal and political thought ( $\mathrm{p} . \mathrm{x}$ ). Contract functioned as a symbol, metaphor, social relation, and material practice that separated freedom from slavery.

Within the ideological construction of contract, premised on selfownership, stood the recurrent question of what could be freely sold. Did the contractual relationship of wage labor make one free or a wage slave? Was marriage an act of contract, or did wives became more like slaves than property-bearing free citizens? How various actors answered these questions was deeply gendered, relating to who was envisioned as a free contractual actor, whose labor could be commodified, whether marriage was the paradigmatic contract of free citizens, and how the home functioned in such constructions.

Stanley posits that wage labor, marriage, and the maintenance of a home and family were vital to nineteenth-century ideas of freedom and contract. All three were intimately connected. A husband's wages theoretically allowed him to maintain a dependent wife, who had consensually entered into marriage. Yet, in practice, marriage and wage labor seemed to undermine freedom. Stanley explores how such concepts stood in tension with one another, in part, by examining a number of legal discourses and how the state, in these areas, exercised power following the Civil War.

Stanley devotes a great deal of attention to the Freedmen's Bureau, and this makes sense, as we can understand it as the first large-scale state regulatory and welfare agency-a prototype for later government action. ${ }^{6}$ Once

5. Yet the question remains as to why so many scholars have chosen to concentrate on this period. Surely the New Deal era or the rise of the women's liberation movement in the 1970s raises equally interesting questions.

6. On March 3, 1865, Congress created within the War Department a "Bureau of Refugees, Freedmen, and Abandoned Lands," commonly referred to as the Freedmen's Bureau. The Bureau became the agency officially in charge of former slaves and shaped the transition from slavery to freedom. 
slaves were emancipated, the Freedmen's Bureau attempted to create a new economic, domestic, political, and moral order across the South. The Bureau preached to freed slaves the importance of entering into and performing labor contracts, and of marriage and monogamy. Freedom was to be built from labor and appropriate domestic relationships. Yet where did freed women fit into such structures and institutions? Were they to be independent laborers, or did the concept of male freedom and citizenship require a dependent wife and family? In practice, these questions became even more complicated. When some freed people refused to marry or enter into labor contracts, Bureau agents, at times, used state force to coerce freed people into both wage contracts and marriage, undermining the essence of their own definition of freedom.

For freedwomen, marriage proved particularly ironic. Freedwomen had emerged from the tyranny of masters who owned their children and had access to their bodies. They now had to contend with husbands who likewise, under regimes of coverture, claimed their labor, property, children, and bodies. Simultaneously, a freedwoman's legal subordination affirmed a freedman's freedom and the (limited) citizenship that he exercised when he made labor contracts binding on his wife, claimed her wages, or sued on her behalf in Bureau courts (Stanley, pp. 48-49).

Yet such courts also became arenas of resistance as freedwomen sought to exercise and create their own definition of freedom, including the right to be free from physical abuse, to receive a husband's financial support in exchange for her domestic labor, and even to leave a husband. Stanley shows how such courts often sided with husbands against wives, affirming freedmen's rights of mastery against women's claims to self-ownership and thus underwriting freedmen's masculinity and citizenship. ${ }^{7}$ Even though freedwomen lost their cases, Stanley shows how they were legal actors who, through their claims to the Bureau, presented themselves as rights-bearing individuals. Such women's actions may have constituted their own assertion of citizenship.

Katherine Franke's "Becoming a Citizen" similarly recognizes the importance of marriage in constructing citizens from slaves, and the coercion that the Freedmen's Bureau employed. As Franke, Stanley, and Ariela Dubler (as we shall see) all recognize, at least part of this mission was to shift the cost of support from the state to the privatized family, where an independent male would support his dependent family (Franke, p. 302). But rather than focusing on the paradoxical nature of marriage for freedwomen, Franke explores the disciplinary power of marriage and how the state, through marriage, forced freed men into a regime of monogamy and forced labor. Franke posits that marriage after emancipation potentially provided for liberatory rights and

7. Linda Kerber (1998) seems to agree with Stanley's claim that the Freedman's Bureau often sided with men affirming their rights to control their wives. 
citizenship, but also produced a bureaucratic regime of discipline and punishment (p. 255).

Before emancipation, slaves in southern states were prohibited from marrying. This ban did not prevent them from participating in nonstatesanctioned marriage and a wide range of other intimate relationships. After emancipation, the southern states passed a variety of laws to promote monogamous marriage among slaves. Some states simply deemed freed couples living together on a certain date to be married automatically. Other states required that former slaves marry formally and file a marriage certificate with the state. Failute to do so while also cohabitating often carried harsh penalties.

In those states that had automatic marriage laws, couples could find themselves married without their knowledge or consent. This fact again supports Stanley's argument that marriage, a mark of freedom, was at times established through state coercion that negated such freedom. Men who cohabited with two women, unaware of their newly married status, found themselves vulnerable to state prosecution for bigamy, adultery, and fornication, and the Freedmen's Bureau, at times, tumed in freedmen to state authorities for prosecution. Franke argues that the prosecution and conviction of freed men for violations of marital norms fed a convict labor system that assured plantation owners a plentiful and inexpensive labor force that replicated the conditions of slavery (pp. 305-7).

Whereas Franke focuses on how the state forced freedmen to perform as male heads of households through labor and marriage, Stanley shows how state force also was soon asserted on African American women. She, along with historians such as Linda Kerber (1988), writes of the double bind that former slave women faced. The Bureau expected freedwomen to maintain an appropriate, clean, and ordered house (always assuming that they had not done so under slavery) as an indicator of female civility, appropriate womanhood, and their husband's potential claims to citizenship. It also, however, expected freedwomen to continue to engage in wage labor, in contradiction to their right as free women not to.

The Bureau and later black codes, through a variety of laws including vagrancy statutes, required that freedwomen labor for wages outside the home, which through coverture, their husbands then controlled. This very labor, however, removed African American women from the ideal femininity of domesticity. Race and gender intersected in creating iterations of domination. As women, married freedwomen came under the dominion of their husbands; as African Americans, they were expected (indeed often forced through vagrancy laws) to engage in wage labor. For a freedman, labor brought him, at least theoretically, closer to full masculinity and citizenship. For a freedwoman, wage labor marked her as less than a lady.

Furthermore, marriage pressed against claims of freedom and newly freed people's understanding of the rights that emancipation brought. Franke quotes one Bureau agent as follows: "[Living] together in a state of concubinage they 
[freedmen] have come to look upon as a privilege, in fact, a right which no one has a right to interfere with" (p. 302). This observation, in turn, raises the question of rights: Did citizenship provide the right to engage in a wide range of sexual, domestic, and intimate relations, as some freed people (as well as others) asserted, or did the very construction of citizenship, the ability to assert rights, require monogamous marriage? In other words, did one have a right to reject marital norms?

This question of the freedom to reject marital norms has propelled some of the best works of gender and legal history. Nancy Cott's Public Vows (2000) explores the variety of forms of intimate relationships before the Civil War and how, following the Civil War, alternative forms of marriage were increasingly foreclosed by the federal government. Thus, in the antebellum period, she (like Hendrik Hartog [2000]) points to Native American marriage practices, self-marriage, separation, bigamy, and interracial marriages. ${ }^{8}$ Further, many utopian communities attempted to restructure radically marriage, gender, and family arrangements. Some of these communities abolished marriage, opting for free love or abstinence. Yet as state and especially federal power grew, this space for alternative domestic practices contracted. In some ways, the work of the Freedmen's Bureau provided the template for later federal action that attempted to mold citizens through monogamous marriage in which the husband functioned as the male head of the family.

As Cott discusses, Congress both outlawed Mormon polygamy and passed the Dawes Act, which broke up Native American land and conveyed it to individual families presumed to be headed by men. Turning to immigration, Cott demonstrates how such laws and policies were related to marriage and profoundly gendered. Federal legislators and authorities sought to transform the immigrant family into an appropriate male-headed household, and immigration law prescribed and legitimized only certain types of marriage. The ideology of marriage required that it be "consensual," grounded in romantic love as opposed to market relationships. Thus, in a very real way, part of the creation of the nation emerged through the enforcement of monogamous marriage and, with it, the male-headed household. ${ }^{9}$

\section{COVERTURE, THE CONTRACTING WOMAN, AND NINETEENTH-CENTURY FEMINISTS AS LEGAL ACTORS}

Much of the literature on gender and legal history seeks to situate firstwave feminists as important legal actors who presented cogent opposition to a

8. An excellent review of Cott's and Hartog's books is Shanley 2002. On Mormon polygamy, see S. Gordon 2002.

9. For a further discussion on immigration, marriage, and picture brides, see Hagg 1999. 
wide range of laws that disadvantaged women. ${ }^{10}$ Foremost was their opposition to coverture and their desire to be free and independent contractual actors. They argued that coverture and a gender system, in part enacted through law, made women economically dependent on men, creating slaves out of wives and denying them the fruits of their labor and even self-ownership. Stanley writes, "The core of the problem was a wife's right to her own labor, wages, and person-a property right that the wage contract presumed but the marriage contract denied" (p. 175).

Where Stanley and scholars such as Nancy Cott (2002) and Norma Basch (1982, 1999) (and, as we will see; Dubler) take these nineteenthcentury feminists at their word regarding how coverture functioned, Hendrik Hartog in his book Man and Wife (2000) produces a more skeptical and ambivalent reading of coverture. Moving from the rhetoric of coverture to the ways that litigants actually used coverture, Hartog discovers women and their lawyers employing it to their own advantage. He writes, "Indeed, one of the oddities of studying lawsuits between separated wives and husbands is the discovery that wives-or their lawyers-so often claimed coverture as a right, against the contrasting claims of husbands that their wives had became competent and capable legal individuals who ought to be held responsible for their own debts" $(2000,38)$. Some women also used coverture, long after their husbands died, as an avenue out of contracts they sought to avoid, and others schemed with debtor husbands to avoid creditors.

Yet exposing the strategic ways in which female litigants used coverture to their own advantage does not negate (and Hartog does not claim that it does) the larger disempowering role that coverture played in creating wives as dependents of men. Further, coverture not only defined wives but also structured concepts of masculinity, affirming men's status and power over women and at least theoretically constructing all men as rational contractual actors who could freely engage in the marketplace while denying women's contractual ability. As it did so, law assisted in creating a domestic sphere of women cleaved from the public world of the marketplace.

An example that encapsulates law's role in creating and reflecting separate spheres through coverture is the notorious case of Bradwell v. Illinois, 83 U.S. 130 (1873). In Bradwell, the U.S. Supreme Court ruled that the Fourteenth Amendment did not prohibit a state from denying admission to the legal bar to women. In his concurrence, Justice Joseph Bradley wrote, "[C]ivil law, as well as nature herself, has always recognized ... the respective spheres and destinies of man and woman. Man is, or should be woman's protector and defender. The natural and proper timidity and delicacy which belongs to the female sex evidently unfits it [sic] for many of the occupations of civil life. The constitution of the family organization ... indicates the domestic sphere as

10. Studying the Declaration of Sentiments that emerged from the Seneca Falls Convention of 1848 , one is immediately struck by how much of it is devoted to calls for legal change. 
that which properly belongs to the domain and functions of womanhood" $(1873,141)$. Bradley also emphasized that the laws of coverture would prevent Bradwell, a married woman, from entering into contracts with her clients. ${ }^{11}$

The Court decided Bradwell the same year as the Slaughterhouse Cases, 83 U.S. 36 (1873). In a strong dissent, Justice Field found that a law providing a supposed monopoly to a certain slaughterhouse in New Orleans was unconstitutional under the Fourteenth Amendment. He wrote that the "right of free labor" was one of "the most sacred and imprescriptibly rights of man" (1873, 110). Read together, Bradwell and Slaughterhouse reflect the way that law not only treated men and women differently but also constructed and then "naturalized" separate spheres, in part through concepts of contract, free labor, and the domestic. Further, as male labor increasingly came to be ideologically constructed as a mark of masculine independence, female dependence on a male (a situation created at least in part by law) completed the picture, underwriting public and private life.

Stanley emphasizes that slave emancipation and the passage of married women's property acts occurred simultaneously. ${ }^{12}$ As slaves were emancipated, freed to engage in contractual labor, women too emerged as contractual agents. Yet, as almost all scholars agree, and as Bradwell illustrates, courts often nullified the effects of these acts, especially as women sought to claim a property right in their own domestic labor (Basch 1982; Siegel 1994a, b). Courts affirmed that a wife owed personal and domestic services to her husband as part of the marriage contract. As women brought claims for wages arising from putting up boarders, housekeeping, nursing, taking in laundry, and doing tenement-house piecework, courts confronted the question of whether this was domestic labor or marketplace wage labor. Were these wages to which a wife was entitled, or were they owned by her husband and more akin to housework than industrial labor? Courts consistently ruled against wives. As Stanley writes, "[O]nly in part did [a wife's] contract rights release her from belonging, body and soul, to her husband... [T] he hireling husband retained a property right in his wife's service that was the entitlement of free men" (p. 217). Thus, courts participated in constructing a masculinity based on entitlement to a wife's services (and access to her body in the form of marital-rape exemptions) and the ability to maintain a home theoretically cleaved from the market. ${ }^{13}$

As Stanley argues, and cases like Bradwell and Slaughterhouse show, legislators, judges, and a variety of reformers invoked the home to justify wage labor, to confirm the male laborer as free rather than a wage slave, and to mark

11. For an insightful article on Bradwell (see Olson 1986).

12. Various state legislatures slowly passed these acts, which generally provided married women with the ability to own property, contract, and own wages (see Basch 1982).

13. On the history of marital-rape exemptions (see Hasday 2000). 
women as noncontractual actors. If wage labor produced porous boundaries between freedom and slavery, home life provided a possible solution, as the family unit was imagined to be inalienable, noncommodified, removed from the market, and the consummate mark of freedom. Stanley writes, "[H]ome life came to represent the proving ground of free contract relations" ( $p$. 148). Yet the more the home was idealized, the more the imagined boundary dividing the market from the home appeared fragile. As social reformers and government statisticians quickly learned, poor women had to work, as a husband's wages could not support a family. Especially troublesome was tenement-house work, which involved the labor of women and children, and in the eyes of many, turned the tenement home into a factory.

From Bondage to Contract, along with the work of Franke, Hartog, and Cott, makes us question some of our basic assumptions about legal history. For example, Stanley's work seriously challenges whether there was a transition from a legal regime based on status to one grounded in contract. ${ }^{14}$ African American men and women and white women remained within a world in which their rights were based on status-a status that deeply implicated their contractual relations. Stanley also undermines historians' understandings of the existence of a regime of laissez-faire in the late nineteenth century. Rather, state force was used in a multitude of ways to require that people labor (or, in the case of white women, refrain from wage labor), ultimately undermining the emancipatory claims of a liberal contractual regime. Related to this, Stanley allows for a different reading of the relationship between the public market and the private sphere of the domestic, demonstrating how they functioned in tandem. The domestic was increasingly positioned as a sentimentalized sphere of organic relationships meant to counterbalance the ruthless sphere of market activity. Yet as the home, especially that of the working class, failed to live up to such ideals, and as market relationships infringed on the home, belief in the utopian possibilities of a laissez-faire regime came into question.

\section{FROM THE PERIPHERY: RESITUATING DOMESTIC RELATIONS LAW}

Using a critical methodology similar to Stanley's, Ariella Dubler explores, through the lens of marriage, the contradictions and instabilities in late-nineteenth-century gender ideology. In doing so, she argues that the status of marriage cast an extraordinarily wide shadow. Like the recent works on marriage discussed above, Dubler's article moves domestic relations law

14. For an excellent essay on the importance of status to law well into the nineteenth century and its continuing resonance, see Siegel 1997. 
from the legal periphery to a central place in shaping law, state power, and the construction of gender. She asserts that we must understand domestic relations law as standing at the heart of law, defining legal status, fashioning identities, and creating women's relationship to the state as one mediated through their husbands. Women, married and unmarried, could claim or were denied various rights and entitlements in connection with their proximity to marriage. In this regard, Dubler, like Stanley, shows the extraordinary power of status, especially for women, well into the twentieth century.

More specifically, Dubler analyzes dower, its role in constructing widowhood, and its eventual demise. Thus Dubler rewrites the narrative of the demise of dower, transforming it from one about the free alienation of property to one about contestations over the family, women, gender, and the state. This claim-that we cannot fully understand the development of inheritance law without accounting for these gendered issues-parallels Stanley's argument that we cannot fully conceptualize the role and inconsistencies of contract unless we analyze gender, race, and the family. Indeed, as historians of law and gender understand, family structure reflects public life, and public life informs the family. Dubler, like Stanley, expands our understanding of who constituted legal actors, putting at the center of her work the active role that women's rights advocates played in abolishing dower.

Dower must be understood against the backdrop of coverture. As previously discussed, the common law of coverture provided that when a woman married, her property became her husband's. In return, a husband had a legal duty to support his wife. Thus, the law created a wife's dependence on het husband. When a husband died, the law provided that a wife was entitled to a one-third life interest in her husband's real property. She had no right to his personal property. Moreover, the widow did not own the dower property outright, but only for her lifetime; thus, she was prevented from selling, or in some cases even improving, that property. Indeed, dower defined the widow as less than a full contractual agent. Her ability to contract, to own, manage, and dispose of property subject to dower was provisional. In contrast, a husband's right to curtesy provided that after a wife's death, he was entitled to the rents, profits, and full use of the property inherited from his wife. Given the material economic disparities between men and women and the ways in which coverture functioned, widows often needed a husband's inheritance to survive. Yet the inequalities between dower and curtesy provided less for widows than for widowers. Moreover, Dubler argues that dower extended the structure of marriage beyond marriage: Wives remained economically dependent on (now dead) husbands.

Like Stanley, Dubler emphasizes how the supposedly private sphere and the public sphere, ostensibly functioning as rigid dichotomy, depended on each other and collapsed into one another. Thus, Dubler argues that dower was inherently contradictory, challenging while simultaneously reifying nineteenth-century conceptions of separate spheres, in which the private 
home constituted women's sphere, and the public world of the market constituted men's sphere. Given that dower rights (which could only be exercised when the husband died) attached to real property at the time of marriage, legally a husband could not sell property without his wife first agreeing to relinquish her future claim over that property. In reality, however, husbands often ignored dower rights, freely selling property without wives' permission. If this kind of transaction occurred, once the wife became a widow, she could sue the purchaser of the property. Thus, dower reflected and created a wife's economic dependence on her husband that confirmed her place in the private. Dower also, however, inserted a wife into her husband's market transactions by permitting her to veto his sale of property by refusing to give up her dower rights. Where coverture removed a wife's ability to contract, dower placed wives into the market and redefined them as at least limited contractual actors. Similarly, Dubler argues that the family home, the subject of dower rights, became a commodity rather than a sanctuary from market forces. Here, we must remember that a wife only possessed a one-third interest in the home and no interest in the personal property contained in the home. This aspect of dower often forced a widow to sell her interest in the home to satisfy other heirs of her deceased husband. Thus, as we see in Stanley's work, in the same way that women's wage labor in tenement homes undermined the home as private and decommodified, so too did dower.

As Stanley (and, as later discussed, Welke) seeks to explicate how masculinity was in part constructed by and reflected in law, Dubler too explains how dower intersected with masculinity. During an era when men's control of property and their ability to enter freely into contracts underwrote male freedom and independence, dower constrained men's absolute freedom. Just as Stanley's work raises significant doubt about whether a legal regime of laissez-faire ever existed, Dubler demonstrates that dower functioned as another site where state power both reaffirmed and undermined masculine power. If a husband wrote a wife out of his will, dower reintroduced her. In connection with a husband's testamentary powers, dower too made him a limited contractual actor. Dower thus produced a masculinity that was at once "powerful and constrained" (Dubler, p. 1667).

Where Hartog's Man and Wife gives little credit to women's rights advocates for initiating tremendous legal change in domestic relations law, Dubler focuses on first-wave feminists' powerful critique of dower and the pressures that they exerted on lawmakers. Like Stanley, Dubler presents such women as important legal actors. The early women's rights movement focused on the inequities of dower as part of its agenda for social, political, and legal reform. Dubler explicates the arguments of the movement and points to its philosophical inconsistencies regarding the meaning of women's equality and the relationship between family and state, public and private. 
Women's rights advocates such as Lucy Stone and Elizabeth Cady Stanton, as well as lesser-known feminists, pointed to dower as one significant example of women's legal subordination to men. Why, they argised, should a widow receive a smaller inheritance through dower than a widower through curtesy? As citizens, they argued, husbands and wives should be entitled to equal legal rights. To the extent that marriage did not provide legal equality, it needed to be restructured by the state.

While arguing that the state was to play a role in creating equality within the family through dower reform, feminist reformers also claimed that dower was an assault by the state on the private family and home. In making this argument, women's rights advocates called on the dominant ideological framework that positioned the domestic as a private, female, and protected space into which the state should not enter. Such reformers continually pointed to the image of the grief-stricken widow losing her home and possessions through dower. Here feminists painted state action as an evil, creating injustice, rather than as a good, leading to equality. Dubler posits that such arguments supported the concept that a wife "was entitled to preserve her wifely, dependent role within the private home after her husband's death" (p. 1681).

Against this background of first-wave feminism's position regarding dower, Dubler examines the demise of dower in New York State. In 1929, New York enacted a new inheritance law that guaranteed an equal elective share to husbands and wives. The committee appointed by the legislature to recommend reforms adopted many of the equality arguments of earlier women's rights advocates. Contemporary feminists, moreover, played a large role in influencing the committee's recommendations. Activist lawyers such as Dorothy Kenyon viewed dower reform as central to creating sex equality. Like earlier feminists, however, she argued that dower reform and the sufficient provision for widows by husbands were necessary to preserve the family after a husband's death. Kenyon also viewed the family as a unit and echoed nineteenth-century feminists' emphasis on the importance of home and the primary purpose of inheritance law as protecting the dependents of a male breadwinner.

This image of the dependent widow and the male breadwinner also drove the committee's conception of dower reform. The committee's central understanding was that marriage required a husband to support his wife financially, even after his death. This argument, like those regarding the importance of marriage following emancipation, reflected a strong belief in the privatization of need. Wives and widows should be dependent on husbands, not on the state. The argument further espoused a traditional view of the roles that husbands and wives were to perform within marriage. Yet the commission also adopted an equality paradigm, asserting that inheritance law should treat men and women in a similar manner. Dubler labels this step as radical, a reflection of the understanding that "legal norms of sex equality would be 
forged within the family" (p. 1688). Thus, the committee, like earlier and contemporary women's rights advocates, simultaneously subverted and reified gender norms.

As the courts began to interpret New York's new elective share law, which gave husbands and wives the ability to claim one-third of the deceased's estate, including real and personal property, a spate of legal issues arose. For example, could a wife by contract with her husband waive her right to an elective share? Were such contracts evidence of a husband's coercive power within the context of unequal power relationships, or should such contracts be upheld as between legal equals? Such questions echoed earlier legal issues regarding the ability to contract out of coverture. ${ }^{15}$ The New York Court of Appeals eventually opined that a wife was always entitled to her interest, even when she had previously agreed to waive it. ${ }^{16}$ The court's language was deeply gendered and made clear that a husband's obligation to support his wife did not end at death.

Arguments and cases such these once again enshrined wives as less than free contractual actors and echoed earlier arguments that supported coverture. As Hartog points out in connection with coverture, supporters claimed that coverture was necessary to protect wives from the coercive powers of husbands. Coverture did so by giving a wife's property to her husband in return for his duty to support her. Yet, as Stanley demonstrates, in a world in which freedom to contract theoretically separated slavery from freedom and self-ownership, women continued to stand outside the liberal contractual paradigm.

This question of women's contracts is crucial to understanding the history of women's relationship to the law. As scholars such as Pamela Hagg (1999), Jane Larsen (1993), Julie Novkov (2001), Sybil Lipschultz (1989), and others have asked: to what extent could a liberal equality paradigm in which women were endowed with the same contractual rights as men produce true equality? To what extent did women need state protection from coercive contracts to produce substantive equality? In part, this is the inconsistency in feminists' arguments that Dubler emphasizes and about which feminists most ferociously disagreed in the 1920s. Some argued that only absolute equality as embodied in the Equal Rights Amendment would liberate women; others maintained that such equality would endanger the protective labor legislation that turn-of-the-century reformers worked so hard to pass and enforce. The position advocating state protection for women is embodied in the 1908 Muller brief to the Supreme Court, written by Josephine Goldmark and Louis D. Brandeis for the National Consumers League. Their argument for limiting the hours of women laundry workers rested on understandings that women's

15. Hartog 2000 provides one of the most sophisticated discussions of this question.

16. See In re McGlone's Will, 17 N.Y.S.2d 316 (App. Div.), rev'd, 32 N.E.2d 539 (N.Y. 1940), aff'd sub nom. Irving Trust w. Day, 314 U.S. 556 (1942). 
primary role was as mothers and wives, and that long work hours endangered a woman's reproductive health and infringed on her ability to function as a mother and wife. ${ }^{17}$ Women thus remained poised between being free contractual actors in the public sphere and noncontractual actors in the domestic sphere.

\section{GENDERING THE SEEMINGLY UNGENDERED}

As discussed above, many scholars of gender and legal history have focused on domestic relations and family law. In such areas, issues of women and gender readily appear. Only more recently have scholars begun to find gender in those areas of law that on the surface appear to be ungendered. Barbara Welke's Recasting American Liberty (2001) genders the history of the tort law of railroad accidents. In doing so, she demonstrates how the history of an area of law that appears unrelated to gender or race takes on an entirely different quality and produces a richer narrative when the historian analyzes such issues. Most important for historical methodology, Welke's work indicates that the legal historian examining almost any area of law can draw on and use gender; we just have to ask the right questions. After all, court cases are about men and women who live gendered lives.

Stanley and Welke also speak to and build on each other, as both explore how the growing regulatory state in the postemancipation era conceptualized and transformed liberty in deeply gendered ways. They and Dubler are also concerned with how masculinity functioned and its relationship to liberty. Did regulation underwrite or undermine a man's liberty? Both Welke and Stanley understand that in the postemancipation era, liberty at its most basic required bodily self-ownership and integrity. Yet what did this vision of liberty mean in a world where a husband had sexual access to his wife's body, where men and women sold their bodies for wages, where one could be maimed for life in a railroad accident?

In the 1870 s, railroad victims were primarily male. Masculinity required men to be autonomous individuals in control of their bodies, independent, physically robust, and actively exercising choice. It also required risk taking. Men's freedom of mobility, one factor that created male liberty, put men at greater risk of injury from train accidents. Men suffered injuries from jumping on and off trains or being hit while walking the rails. This risk of injury was the trade-off that men paid for their freedom. While men were expected to engage in such risky activities, and railroads actively encouraged some of this behavior, doctrines of contributory negligence prevented recovery from railroads. The autonomous man was responsible for his own well-being. Yet, as

17. For discussions on Muller, 208 U.S. 412 (1908), see, e.g., Erickson 1982; Lipshultz 1989; Hart 1994; Woloch 1996. 
Welke writes, railroads made men vulnerable to injury and removed men's ability to control their surroundings, infringing on men's liberty.

By the early twentieth century, as women's access to public space grew, they too suffered injuries from trains and streetcars. Women's injuries produced greater cultural dissonance than men's injuries. They highlighted women in public space as opposed to the protected space of the home. Welke demonstrates that such injuries were gendered, as women's long skirts caught on protrusions, or as mothers fell carrying infants while exiting cars. These were women who appeared to need protection. Gender also shaped how courts treated men and women's claims for railroad injuries. Men "suffered from the assumption of ableness"; by contrast, women invoked the presumption of frailness and dependence (p. 43). Presumed incompetent, governed by emotion rather than reason, and unable to fully comprehend danger, women's contributory negligence was excused by courts and juries, especially when women were acting on the advice of trainmen. Women were entitled to rely on men's directions (pp. 91-92). This standard demeaned women's agency but paradoxically worked in at least some women's favor.

Such a female face of pain and vulnerability provoked state intervention and protection. Welke argues that courts, administrative agencies, and legislatures continually expanded the duty of railroads to protect the individual and asserts that this duty, in part, was due to the large number of women who brought suit against railroads. In a sense, the regulation of railroads tracked the development of protective labor laws upheld for women but at first struck down for men as an infringement on liberty. Thus, we might understand the rise of the regulatory state as at least in part a response to the perception that women needed protection. ${ }^{18}$

The types of injury suffered by men and women also differed. Men were killed, lost limbs, suffered severe head injuries; these were external injuries. Because they were so visible to the naked eye, male plaintiffs did not have to articulate their physical pain to make it real to juries. Women, however, often suffered internal injuries affecting their spines and ligaments, their nervous and reproductive systems. And it was women who most often successfully brought claims for pain and suffering (Welke, p. 128). To claim pain and suffering required a public narration of weakness, vulnerability, and fragility, traits deemed feminine. Welke argues that courts' acceptance of women's pain and suffering resulted in the expansion of negligence law and, further, laid the groundwork to provide a cause of action for "nervous shock."

As Welke poignantly documents, train accidents did not just damage those who suffered immediate physical injury but also those who witnessed scenes of carnage. Although physically unscathed, some witnesses to train disasters later began to suffer physical and mental injury diagnosed by the

18. On the role of gender and the rise of the regulatory state, see L. Gordon 1994; Skocpol 1992; Goodwin 1997. 
medical profession as "nervous shock." Seemingly solid men complained of symptoms that in women would have been diagnosed as hysteria, and physicians strained for explanation. One doctor testified that as a "direct outcome of nervous shock of a railway collision, men become no less emotional and hysterical than [women]" (Welke, p. 174). The near-fatal miss, the vulnerability that came with modernity, had the disturbing capacity to make men act as women. Defense attorneys asserted that allowing male plaintiffs to make claims for nervous shock would create a nation of men without courage or character, and that such men belonged "at home in petticoats" (p. 200). In other words, such men were more like women.

By contrast, women's claims were more successful and framed differently. Women often asserted that train accidents produced nervous shock that then resulted in a miscarriage of pregnancy. Constructions of femininity made such claims resonate. Courts and juries found women justified in their fright, and drew a connection between a woman's mental state and its physical manifestations. As long as the number of women litigants remained small, they comprised the exception to the rule. In other words, women stood outside the norms of law; by definition, they were not "reasonable men."

By the first decade of the twentieth century, however, women's claims against railroads dramatically increased. No longer were women the exception, but the rule itself. Welke astutely argues that appellate courts and legal treatise writers searching for (and creating) national uniformity and abstract legal rules incorporated cases involving women. To a certain extent they had to, as so many of the cases, especially on the appellate level, involved women. In doing so, they erased the gender of litigants. Thus, generalizing from cases involving women, sometimes pregnant women, appellate courts and treatise writers fashioned a new law of negligence. Welke writes, "In so doing they masked the significance of gender in the articulation of the rule. And they made rules articulated in cases involving women apply to all injured persons. ... In turn, lawyers and judges, in cases involving injury to men, borrowed from precedents involving women" (p. 103). Negligence law was thus feminized.

In the process, masculinity and liberty took on new configurations. The characteristics most associated with late-nineteenth-century women, vulnerability and victimhood, began to define all individuals. As state railroad commissions, legislators, and (more subtly) courts created safety regulations, men's liberty to engage in certain behavior was circumscribed. Men (as well as railroads) no longer were subject only to their own judgment but to state regulation. To keep bodies free of pain, to provide an inviolate right to a body, required the curtailment of male liberty. Injury was no longer the price of liberty but an impediment to liberty.

Welke's critical analysis parallels Stanley's in how concepts of freedom and liberty double back on themselves. As Stanley argues, freedom of contract. often involved state force. Likewise, as Welke postulates, liberty ultimately 
required constraint. Furthermore, Dubler, Stanley, and Welke all demonstrate that conceptions of separate private and public spheres were increasingly challenged on numerous fronts by the late nineteenth century. Dubler emphasizes that as the private home was subject to dower, it took on the quality of a commodity subject to litigation and sale. Stanley demonstrates how through homework and piecework, the home became a site of wage labor rather than a refuge from it, undermining the promise of free labor ideology that the family was not to be a commodity. Welke subtly argues that trains and train accidents challenged distinctions between public and private, as the noise from trains invaded living space and the explosions from collisions and even runaway trains resulted in injuries to women in their homes. Thus, each explicates how the public and private dichotomy, so crucial to nineteenth-century ideology, increasingly appeared threatened. From this we can further see how the state sought to regulate a multitude of areas in a perhaps futile attempt to protect and insulate the domestic sphere from the market. ${ }^{19}$

Like Stanley, Welke provides new ways of comprehending latenineteenth-century law. Welke's description of the outcome of treatise writers' quest for legal abstraction and uniform laws stands in stark contrast to our dominant narrative of legal history and the shift to formalism or orthodox legal thought. This dominant narrative tells us that such a transition in jurisprudence was profoundly conservative and intended to mask substantive and class inequalities. Furthermore, it impeded the regulatory state, externalizing the cost of injury on those who could least afford it, and preventing the redistribution of wealth. ${ }^{20}$ In contrast, Welke argues that uniformity and abstraction furthered the regulatory state by bringing law, developed within specific contexts and intended to apply to women, into the larger body of negligence law and, in the process, erasing its gendered and feminized aspects.

\section{THEORIZING THE INTERSECTIONS OF RACE AND GENDER}

Welke, like Stanley and Dubler, also demonstrates the continuing importance to law of status. This point becomes increasingly vivid as Welke analyzes how gender and race functioned in the lawsuits that plaintiffs brought challenging segregated rail travel. Unlike their European counterparts, and reflecting the myth of a classless society, railroad cars in America, at

19. For this argument see Batlan 2002.

20. Morton Horwitz $(1977,1992)$ has forcefully presented this narrative. See also Wiecek 1998; Hall 1989. 
least initially, did not have a first and second class. Welke, however, shows that there nonetheless were segregated cars, in which class, race, and gender played interlocking and changing roles. From an early date, railroads provided "ladies' cars." These cars offered comforts such as water dispensers, bathrooms, and plush seats. Passengers in these cars were banned from smoking or using foul language. Moreover, these cars, situated at the end of the train, protected their occupants from head-on collisions and from the dirt and heat produced by the engine. Theoretically, the cars were open to all women and those men who accompanied them. As ladies' cars produced a female sphere of more refined railroad travel, other cars dubbed "smoking cars" fostered a male world of smoking, spitting, card playing, and rough language, a place where a true lady would not venture. ${ }^{21}$

Following slave emancipation and before the full advent of Jim Ctow laws, railroads confronted the question of where to seat African American women. ${ }^{22}$ The practice quickly arose of requiring them to ride in smoking cars or assigning all African Americans to racially segregated space. Enforcement, however, was sporadic and depended on the whim of the conductor or the complaints of white passengers. When conductors did eject African American women from ladies' cars or blocked their access to them, they often used significant physical force. Some African American women did not passively accept such assignment, bringing suits against railroads in which they claimed a right to ride in the protected space of the ladies' car. To occupy such space was to claim a status of free women who had the means to travel. It was to make a claim to middle-class ladyhood and respectability that transmuted into a legal right to occupy certain space. Thus, like Stanley, Welke portrays African American women with significant agency, demonstrating how at certain moments these women called on state power (a state that often was hostile) to enforce what they understood to be their rights.

Welke perceptively writes that African American women, at least those who appropriately performed the role of respectable womanhood, used "the status hierarchy of gender against that of race" in bringing legal claims (p. 296). Railroads steadfastly fought these suits, claiming that such women were not ladies, that they were sexually promiscuous (in large part, by virtue of their race), and that allowing African American women (and African American men who accompanied them) into such protected space endangered white women. Railroad lawyers implied that by virtue of race, ladyhood was impossible for African American women to obtain. These claims also reflected on African American men's masculinity, for they could not protect their wives nor gain recognition of their own middle-class status through their

21. Amy Richter (2000) argues that at the turn of the century, trains increasingly became conceptualized as domestic feminine space, creating what she calls a "public domesticity."

22. C. Vann Woodward (1955) has written the classic work on the advent of Jim Crow in the South. Glenda Gilmore (1996) more recently has analyzed how gender functioned in the creation of a segregated south. 
wives. ${ }^{23}$ Yet, at least in the years before Jim Crow, African American women won a surprising number of these cases, especially in federal court. Welke's discussion also demonstrates how different constellations of rights such as the right to be classified and treated as a lady-things that we often do not perceive as legal rights-emerge when race and gender, and particularly their intersection, are read into law.

Welke also asserts that southern segregation reverberated and encroached on the prerogatives of white men. By 1901 , every southern state had enacted laws mandating racial segregation on railroads. Welke writes, "Jim Crow replaced gender with race" (p. 319). Such laws both regulated African Americans and restricted the freedom of movement and access to space so significant to white masculinity. Whites on railroads now by law had to yield space to blacks. Thus, white men became regulated, as did African Americans. Like Dubler and Stanley, Welke demonstrates how law increasingly constrained men and masculine prerogative.

In the years following the advent of legal segregation, whites began to bring suits against railways for failing to maintain segregated space. In such suits, the status of whiteness became a property right deeply intertwined with gender. ${ }^{24}$ White women sued railroads for the fear and anxiety they suffered when finding themselves next to African American men. Welke writes that more than any other group, such women won their suits at the trial and appellate level. White women also brought and won suit when conductors wrongly ordered them out of white space, incorrectly assuming that they were African American. As such women, wrongly removed from white space, invoked the trope of endangered southern white womanhood in courtrooms, white male judges, jurors, and attorneys enacted white southern manhood by protecting these white women from both the imagined threat of black men and the corporate power of railroads.

Welke's analysis demonstrates how gendered readings of seemingly ungendered categories change our narratives of legal history, complicating our assumptions about who brought lawsuits, how such claims were made, where change over time can be located, and how legal doctrine developed. Welke also makes an even larger claim about modernity and gender, positing that the conditions of modernity created a feminization of men or, at least, a reconfiguration of masculinity. Thus, she argues that the conditions of modern life rendered the individual passive, vulnerable, not fully in control of his environment, and a perpetual potential victim. Such conditions gave rise to the regulatory state and also undermined nineteenth-century ideals of the autonomous, free man. ${ }^{25}$

23. Thorstein Veblen (1899) made the now-classic argument regarding how women convey the class status of their husbands.

24. An important article on whiteness as a form of property is Harris 1993.

25. It is certainly worth pondering how Welke's conclusions affirm or contradict some of the assertions that historian Gail Bederman (1995) reaches. Bederman argues that during the 


\section{RACE, GENDER, AND THE LEGAL PROFESSION}

All the scholars discussed above bring a sophisticated analysis of gender to their work and expand our knowledge of the ways in which women functioned as legal actors, whether as reformers, litigants, or both. Surprisingly, however, this scholarship pays scant attention to the minuscule but growing number of women who began entering the legal profession in the latter part of the nineteenth century. Even Dubler, who references Dorothy Kenyon, an attorney with a remarkable legal career, makes little mention of her work as a lawyer, instead seeing her primarily as a women's rights activist. ${ }^{26}$ Further, much of the scholarship that exists regarding the history of women in the legal profession is descriptive and does not engage in the deep critical analysis of gender as seen in the works discussed. Thus, these two bodies of scholarship on the history of gender and the law are not fully integrated, nor do they engage in dialogue with each other. This situation may be changing, as evidenced by Kenneth Mack's "A Social History of Everyday Practice. Mack's article enhances our understanding of women in the legal profession, the everyday practice of law, and how race, gender, and class functioned in lawyers' professional lives. It is also a drastic departure from the older conception of lawyers' biographies in which a life is portrayed as a series of cases and professional successes. Instead, as in the work of Stanley, Dubler, and Welke, Mack blurs the boundaries between the public and the private.

Sadie Tanner Mosell Alexander, the focus of Mack's article, was Pennsylvania's first African American woman attorney. In the course of her professional life, she created a thriving law practice, played an active role in the civil rights struggle, and eventually sat on a presidential commission. Rather than writing a story of the exclusion of black women from the legal profession, Mack focuses on how Alexander's everyday practice and class position allowed her to gain power and prestige within first the local bar and, eventually, a wider arena.

Mack begins with the accepted history, propounded by scholars such as Jerrold Auerbach (1976), that elite bar associations and lawyers attempted to close ranks as women, immigrants, and African Americans sought to join the profession. He then asks how such people, facing blatant discrimination, were able to forge successful legal practices and careers. In doing so, Mack explores the role of African American women lawyers. More broadly, however, he also is concerned with explicating the everyday practice of law-the historical question of what twentieth-century lawyers actually did in their legal practices and how such practices interacted with and reflected local

first decades of the twentieth century, middle-class men embraced a new more aggressive masculinity.

26. Kenyon's papers are located in the Sophia Smith collection at Smith College. 
communities. ${ }^{27}$ Further, like Stanley, Franke, and Welke, Mack demonstrates yet another way that African American women used the law to their own benefit via a strategy that combined the complex interplay of gender, class, and race.

In 1927, Sadie Alexander, who already held a doctorate in economics, graduated from the University of Pennsylvania Law School-the first black woman to do so. Like many women lawyers in the early part of the twentieth century, Alexander joined her husband's office and practiced probate and domestic relations law, areas that male lawyers found insufficiently exciting, as they did not allow for jury trials. ${ }^{28}$ Mack writes that such work "might be viewed as both conventional women's work that relegated them to the bottom of the profession, and as protected niches that allowed black women to define their role in the legal profession" (p. 1436). Thus Mack recognizes Alexander's agency and the larger constraints she faced as an African American woman within the legal profession. In doing so, Mack exhibits the same comfort with ambiguity, with multiple possibilities, that Stanley, Dubler, and Welke bring to their work.

In Philadelphia, many African American institutions, such as churches, newspapers, banks, hospitals, and undertakers, served the growing African American population. Such growth was fueled in part by the great migration of the 1920s, which gave life to new black enterprises and in turn generated continual legal work. From these African American businesses, the Alexander firm drew its clientele. Sadie Alexander was not beyond exploiting arrangements that increased the firm's business and her own reputation in the community. For instance, she agreed to provide an African American newspaper with details of her divorce cases in exchange for favorable firm publicity. She also wrote letters for clients to gain credit from Philadelphia department stores while directing clients' business to such stores. As Mack writes, Alexander "traded on her reputation" (p. 1450).

Here again, as with Welke, in connection with ladies' cars, we see the importance of reputation for African American women. Reputation and status, a combination of gender and class, were tangible assets that middleclass African American women used to battle the white supremacism and sexism they faced. Indeed, Mack places Alexander in the tradition of African American female respectability (White 1999; Hunter 1997). At a time when

27. On the point of what late-nineteenth-century elite lawyers actually did on a day-today basis, see R. Gordon 1984. Louis Anthes (2003) asks similar questions about how earlytwentieth-century immigrant attorneys were able to build successful law practices by catering to the legal needs of other immigrants.

28. Virginia Drachman $(1998,1993)$ beautifully explores the late-nineteenth-and earlytwentieth-century debate as to whether women lawyers were suited to conduct jury trials. She examines how male lawyers viewed the question, as well as women lawyers' own understanding. Eventually, office work came to be understood as more appropriate for women attorneys. See also Morello 1986. 
most African American women were denied respectability, Alexander embodied and perfectly performed bourgeois respectability. As demonstrated in the cases of African American women who demanded access to ladies' cars, the law in its various manifestations could confirm respectability to women who participated whether as plaintiffs or lawyers in the legal system.

Mack finds (confirming the work of other historians) that most of the divorces that Alexander handled were based on desertion and uncontested. Thus, Alexander's practice depended on high volume rather than large and complicated cases. Drawing together social history, African American history, and legal history, Mack emphasizes that Alexander's practice reflected the mobility of the city's African American population. Many of her cases involved desertions and bigamous clients who had left spouses in the South and remarried in the North. As Hartog (2000) writes of the frequency of bigamy in the nineteenth century as men deserted their families, moved, and remarried, Mack anecdotally points to the continuation of such patterns well into the twentieth century. In this context, Mack writes, Sadie's practice began to resemble social work (p. 1445), and it was deeply rooted in and part of the community. This insight raises the important question of the porous and gendered boundaries that distinguish legal practice and social work. ${ }^{29}$

By 1940, through a growing reputation and her active church involvement, Alexander attracted the A.M.E. Church, the largest African American landowner in Philadelphia, as a client, and she represented it in real estate, tax, and other matters. Such legal work gave Alexander enhanced visibility, resulting in new clients. Through the church, Alexander combined her legal skills and religious devotion, often dealing with sensitive and intimate matters. As Evelyn Higginbotham (1993) writes, African American women played an enormous role in African American churches as volunteers who often took leadership positions. With Alexander, we see how women's volunteer work also could be parlayed into professional work and opportunity. Alexander's position as a middle-class black women attorney with deep roots in the church and community organizations situated her as someone to whom other religious women could turn for legal advice. For instance, Alexander represented a number of women in divorce cases against husbands who were church pastors.

Alexander's religion and her steadfast respectability influenced how she practiced law and increased her legal reputation. Here Mack opens up a new paradigm of understanding. We ordinarily conceptualize twentieth-century legal practice as entirely secular. Even when legal biographies discuss religion, they often segregate the issue into the subject's private life. Mack refuses to compartmentalize Alexander's public and private life and shows how religion, gender, race, and class informed her personal life and her legal practice. This

29. On the development of social work, see L. Gordon 1988; Kunzel 1993; Walkowitz 1999. 
was especially so in the divorce and probate context, where respectability and morality influenced the outcome of cases. Even in areas seemingly removed from religion and church work, Alexander, in representing clients, combined appeals to morality, Christianity, middle-class ideals, and her various social and community relationships. By explicating the ideology under which Alexander functioned, Mack demonstrates the impossibility of separating the public and private spheres.

By the 1950s, Alexander was an extraordinarily practiced lawyer and a powerful negotiator who shared class-based assumptions and experiences with the black middle-class of Philadelphia, making her an effective communicator and advocate. Alexander's reputation became national when President Truman named her to a presidential commission to study race relations in the United States. This appointment opened new doors, and Alexander soon was involved with a host of civil rights organizations while her husband became the city's foremost civil-rights litigator.

Although Alexander's life was unique, it also provides a window into the lives of other African American women who began practicing law before World War II by doing "women's legal work." Using such a base, these women forged their practices and, like their white counterparts, often specialized in areas involving domestic relations law. Mack contrasts this first generation of African American women lawyers, who were willing to accept low-status women's legal work, with the second generation. For example, secondgeneration African American women lawyers such as Pauli Murray challenged their exclusion from elite legal institutions on grounds of gender and race, and refused to take a subordinate position to men. In contrast, Alexander's advice to African American women lawyers, at times, included that such women should "marry a black lawyer" and professionally affiliate themselves with men (Mack, p. 1470). At least at certain moments, Alexander crankily viewed second-wave feminism as destroying a husband's obligation to support his wife. Here Alexander's views might be compared to Dorothy Kenyon's perception, as explicated by Dubler, regarding dower reform and the continuing obligation of husbands to support wives.

Mack writes that we must historically situate and contextualize Alexander's life. She was a woman who broke tremendous barriers but also was steeped in late-nineteenth century gender ideology. Alexander accepted that men and women had separate roles to play in family and professional life, with distinct, complementary obligations and responsibilities. Women's legal work reflected their caregiving roles. As Mack writes, "The relationship between gender, power, and domination could change with time, making what was subordinate at one moment liberating at another" (p. 1472). Mack's insight here is especially important for, as does recent gender theory, it eliminates concepts of false consciousness and situates Alexander in a time and place that presented extraordinary barriers but also opportunities and the possibility to exert what Mack calls "ironic power" (p. 1473). 


\section{CONCLUSION}

Ironic power conveys many of the ambiguities and contestations that so much of the literature on gender and legal history highlights. For example, Dubler's women's rights advocates asserted their own power and argued for a potentially subversive family equality while also employing the very discourses of dependency that helped create women's inequality. Such arguments reflected women's economic need but also the powerful hold of the privatized family. Welke's female plaintiffs used culturally sanctioned narratives of female fragility and weakness to win lawsuits, ultimately and unintentionally transforming negligence law. Stanley's discussion demonstrates how freedom placed freedwomen into a regime of coverture that in part abrogated the self-ownership that emancipation promised. Yet even here, freedwomen brought claims against their husbands for the benefits that coverture conferred.

Stepping back for a moment, I want to emphasize certain similarities in the literature discussed here. Methodologically, all the works use a blend of source material, which reaches far beyond court cases. Like much of the new legal history, they rely on legislative proceedings, administrative hearings, bar minutes, newspapers, letters, speeches, church proceedings, the writings of participants in social movements, fiction, and the flotsam of popular culture. They thus continue to expand our concept of the sources that we can use in constructing narratives of legal history. Looking beyond traditional legal sources, they find new legal actors. More specifically, they locate how a wide range of women functioned in the legal system and how some sought to transform law as part of a broader and potentially radical agenda for social change.

By employing such sources, these works moreover question where law can be located and what constitutes law, denying that law is in any way a closed or autonomous system. Rather, they take as their premise that law reflects societal understandings of gender while simultaneously constructing such understandings. Indeed, they perceive gender as crucial to understanding legal thought itself.

These works are also transformative of the stories that we seek to tell about law. They redraw our understandings of which historical moments constitute continuities and ruptures. They also change our perspective, telling us that we cannot understand the "public" of law, without understanding the supposedly "private" of the domestic. As Dubler and Stanley make so clear, the public produced the private, and the private produced the public. Moreover, they provide further insight into the development of the regulatory state. As Welke concludes in connection with tort law, the modern law of railroad accidents had a feminizing effect because it applied law to men that was originally designed to protect women. This conclusion can be expanded to cover much of the modern regulatory state. That is, laws designed to 
protect women and, often, the home itself, such as labor laws for women, slowly became applicable to men.

We are also just beginning to conceptualize the relationship between law and masculinity, and many questions remain, especially as we take into account race and class. Indeed our present understanding of masculinity may be too reductive and static, and we must remember that at any historical moment there are competing masculinities. For instance, Dubler, Stanley, and Welke all conceive of late-nineteenth-century masculinity as at least partially based on freedom from state-imposed constraints. Yet does this represent too much of an idealized masculinity, removed from the ways in which men, even white men, lived their lives? Furthermore, do such claims lack historical specificity? Were men ever free from state restraint? Is it not the case that all states impose some form of restraint? This, of course, begs the further question of which men we are discussing and how, at various historical moments, claims to certain types of liberty construct both masculinity and citizenship. An ongoing analysis of masculinity is crucial for gender and legal history, allowing us to understand gender as relational and as about evershifting constructions of power.

Finally, we must continue to write gender into those areas of legal history that remain ungendered. In doing so, we should constantly ask ourselves how race and gender are intertwined. As Stanley, Welke, and Mack demonstrate, paying attention to gender and race allows for new insight regarding issues as diverse as how law was practiced, who was subject to regulation, what role the family played in constructing citizenship and nation, and how gender influenced the ways in which individuals could make legal claims on the state and through private suit. Following in the footsteps of what is becoming a rich body of literature on gender and legal history, we might begin to imagine what a gendered legal history might look like in areas that remain entirely ungendered.

\section{REFERENCES}

Abrams, Kerry. 2005. Polygamy, Prostitution, and the Federalization of Immigration Law. Columbia Law Review 105:641-716.

Anthes, Louis. 2003. Lawyers and Immigrants, 1870-1940: A Cultural History. Levittown, N.Y.: LFB Scholarly.

Auerbach, Jerrold. 1976. Unequal Justice: Lawyers and Social Change in Modern America. New York: Oxford University Press.

Basch, Norma. 1982. In the Eyes of the Law: Women, Marriage, and Property in NineteenthCentury New York. Ithaca, N.Y.: Cornell University Press.

- 1999. Framing American Diworce: From the Revolutionary Generation to the Victorians. Berkeley and Los Angeles: University of California Press.

Batlan, Felice. 2002. A Reevaluation of the New York Court of Appeals: The Home, the Market, and Labor, 1885-1905. Law and Social Inquiry 27: 489-528.

Bederman, Gail. 1995. Manliness and Civilization: A Cultural History of Gender and Race in the United States, 1880-1917. Chicago: University of Chicago Press. 
Cahn, Naomi. 2002. Faithless Wives and Lazy Husbands: Gender Norms in Nineteenth Century Divorce Law. University of Illinois Law Review 2002:651-98.

Carnes, Mark, and Clyde Griffen. 1990. Meanings of Manhood: Constructions of Masculinity in Victorian America. Chicago: University of Chicago Press.

Chused, Richard. 1985. Late Nineteenth Century Married Women's Property Acts by Courts and Legislatures. American Joumal of Legal History 29:3-35.

Cott, Nancy. 2000. Public Vows: A History of Marriage and the Nation. Cambridge, Mass.: Harvard University Press.

Drachman, Virginia. 1998. Sisters in Law: Women Lawyers in Modern American History. Cambridge, Mass.: Harvard University Press.

- 1993. Women Lawyers and the Origins of Professional Identity in America: The Letters of the Equity Club, 1887 to 1890. Ann Arbor: University of Michigan Press. Erickson, Nancy. 1982. Historical Background of "Protective" Labor Legislation: Muller v. Oregon. In Women and the Law: A Social Historical Perspective, ed. D. Kelly Weisberg. Vol. 2. Cambridge, Mass.: Schenkman.

Findlay, Eileen Suarez. 1999. Imposing Decency: The Politics of Sexuality and Race in Puerto Rico. Durham, N.C.: Duke University Press.

Gilmore, Glenda. 1996. Gender and Jim Crow: Women and the Politics of White Supremacy in North Carolina, 1896-1920. Chapel Hill: University of North Carolina Press.

Goodwin, Joanne L. 1997. Gender and the Politics of Reform: Mothers' Pensions in Chicago, 1911-1929. Chicago: University of Chicago Press.

Gordon, Linda. 1988. Heroes of Their own Lives: The Politics and History of Family Violence, Boston 1880-1960. New York: Viking.

. 1994. Pitied But Not Entitled: Single Mothers and the History of Welfare. New York: Free Press.

Gordon, Robert. 1997. Forward: The Arrival of Critical Historicism. Stanford Law Review 49:1023-30.

-1984. The Ideal and the Actual in the Law. In The New High Priests: Lawyers in Post-Civil War America, ed. Gerard W. Gawalt. Westport, Conn.: Greenwood Press.

Gordon, Sarah Barringer. 2002. The Mormon Question: Polygamy and Constitutional Conflict in Nineteenth Century America. Chapel Hill: University of North Carolina Press.

Grossberg, Michael. 1985. Governing the Hearth: Law and Family in Nineteenth-Century America. Chapel Hill: University of North Carolina Press.

- 1990. Institutionalizing Masculinity: The Law as a Masculine Profession. In Meanings of Manhood: Constructions of Masculinity in Victorian America, ed. Mark Carnes and Clyde Griffen. Chicago: University of Chicago Press.

Haag, Pamela. 1999. Consent: Sexual Rights and the Transformation of American Liberalism. Ithaca, N.Y.: Cornell University Press.

Hall, Kermit. 1989. The Magic Mirror: Law in American History. New York: Oxford University Press.

Harris, Cheryl. 1993. Whiteness as Property. Harvard Law Review 106:1707-91.

Hart, Vivien. 1994. Bound by Our Constitution: Women, Workers, and the Minimum Wage. Princeton, N.J.: Princeton University Press.

Hartog, Hendrick. 2000. Man and Wife in America: A History. Cambridge, Mass.: Harvard University Press.

Hasday, Jill Elaine. 2000. Contest and Consent: A Legal History of Marital Rape. California Law Review 88:1373-1505.

2002. Parenthood Divided: A Legal History of the Bifurcated Law of Parental Relations. Georgetown Law Joumal 90:299-386.

Hoff-Wilson, Joan. 1991. Law, Gender, and Injustice: A Legal History of U.S. Women. New York: New York University Press. 
Horwitz, Morton, 1977. The Transformation of American Law, 1780-1860. Cambridge, Mass.: Harvard University Press.

- 1992. The Transformation of American Law, 1870-1960. New York: Oxford University Press.

Higginbotham, Evelyn Brooks. 1993. Righteous Discontent: The Women's Movement in the Black Baptist Church, 1880-1920. Cambridge, Mass.: Harvard University Press.

Hunter, Tera. 1997. To 'Joy My Freedom: Southern Black Women's Lives and Labors After the Civil War. Cambridge, Mass.: Harvard University Press.

Jones, Carolyn. 1994. Dollars and Selves: Women's Tax Criticism and Resistance in the 1870s. University of Illinois Law Review 1994:265-309.

Kerber, Linda. 1998. No Constitutional Right to Be Ladies: Women and the Obligations of Citizenship. New York: Hill and Wang.

Kunzel, Regina. 1993. Fallen Women, Problem Girls: Unmarried Mothers and the Professionalization of Social Work, 1890-1945. New Haven, Conn.: Yale University Press.

Larsen, Jane. 1993. Women Understand So Little, They Call My Good Nature "Deceit":

A Feminist Rethinking of Seduction. Columbia Law Review 93:374-472.

Lipschultz, Sybil. 1989. Social Feminism and Legal Discourse, 1908-1923. Yale Journal of Law and Feminism 2:131-60.

Minow, Martha. 1985. "Forming Underneath Everything that Grows": Toward a History of Family Law. Wisconsin Law Review 1985:819-98.

Morello, Karen Berger. 1986. The Invisible Bar: The Woman Lawyer in America, 1638 to the Present. New York: Random House.

Novkov, Julie. 2001. Constituting Workers, Protecting Women: Gender, Law, and Labor in the Progressive Era and the New Deal Years. Ann Arbor: University of Michigan Press.

Nye, Robert. 2005. Locating Masculinity: Some Recent Work on Men. Signs 30:193762.

Olson, Francis, E. 1986. From False Paternalism to False Equality: Judicial Assaults on Feminist Community. Michigan Law Review 84:1581-41.

Richter, Amy. 2000. Tracking Public Culture: Women, the Railroad, and the End of the Victorian Period. PhD diss., New York University.

Scott, Joan. 1986. Gender: A Useful Category of Analysis. American Historical Review 91:1053-75.

Shanley, Mary Lyndon. 2002. Public Values and Private Lives: Cott, Davis, and Hartog on the History of Marriage in the United States. Law and Social Inquiry 27:923-39.

Siegel, Reva B. 1994a. Home as Work: The First Woman's Rights Claims Conceming Wives' Household Labor, 1850-1880. Yale Law Joumal 103:1073-217.

-1994b. The Modernization of Marital Status Law: Adjudicating Wives Rights to Earnings, 1860-1930. Georgetown Law Journal 82:2127-211.

- 1997. Why Equal Protection No Longer Protects: The Evolving Forms of StatusEnforcing State Action. Stanford Law Review 49:1111-48.

Skocpol, Theda. 1992. Protecting Soldiers and Mothers: The Political Origins of Social Policy in the United States. Cambridge, Mass.: Harvard University Press.

Stoler, Ann Laura. 1995. Race and the Education of Desire: Foucault's History of Sexuality and the Colonial Order of Things. Durham, N.C.: Duke University Press.

White, Deborah, Gray. 1999. Too Heawy a Load: Black Women in Defense of Themselves, 1894-1994. New York: W.W. Norton.

Van Burkleo, Sandra. 2001. Belonging to the World: Women's Rights and American Constitutional Culture. New York: Oxford University Press.

Veblen, Thorstein. 1899. The Theory of the Leisure Class. New York: Macmillan.

Walkowitz, Judith. 1992. City of Dreadful Delight: Narratives of Sexual Danger in Late Victorian London. Chicago: University of Chicago Press. 
Wiecek, William. 1998. The Lost World of Classical Legal Thought. New York: Oxford University Press.

Woloch, Nancy. 1996. Muller v. Oregon: A Brief History with Documents. Boston: Bedford/St. Martin.

Woodward, C. Vann. 1955. The Strange Career of Jin Crow. New York: Oxford University Press.

Zaher, Claudia. 2002. When a Woman's Marital Status Determined Her Legal Status: A Research Guide on the Common Law Doctrine of Coverture. Law Library Joumal, summer, p. 459. 